\title{
Cytogenetic divergence in two sympatric fish species of the genus Astyanax Baird and Girard, 1854 (Characiformes, Characidae) from northeastern Brazil
}

\author{
Aline Souza Medrado ${ }^{1}$, Mavione Souza Ribeiro ${ }^{2}$, Paulo Roberto Antunes de Mello Affonso ${ }^{2}$, \\ Paulo Luíz Souza Carneiro ${ }^{2}$ and Marco Antônio Costa ${ }^{1}$ \\ ${ }^{1}$ Departamento de Ciências Biológicas, Universidade Estadual de Santa Cruz, Ilhéus, BA, Brazil. \\ ${ }^{2}$ Departamento de Ciências Biológicas, Universidade Estadual do Sudoeste da Bahia, Jequié, BA, Brazil.
}

\begin{abstract}
The fish genus Astyanax is widespread throughout the Neotropical region and is one of the most species-rich genera of the Characiformes. Cytogenetic studies of Astyanax have revealed marked intra- and interspecific diversity, with the identification of various species complexes. In this report, we describe the karyotypic structure of two sympatric species of Astyanax (Astyanax sp. and Astyanax aff. fasciatus) from the Middle Contas River basin in the northeastern Brazilian state of Bahia. Both species had $2 n=48$ but differed in their karyotypic formulae. Small heterochromatic blocks and multiple nucleolar organizer regions (NORs) were identified in both species. Terminal $\mathrm{CMA}_{3}{ }^{+} / \mathrm{DAPI}$ signals were observed in Astyanax sp. and A. aff. fasciatus, mostly coincident with NORs. These results show that chromosomal markers can be used to identify species in this fish complex. These markers can provide useful information for evolutionary studies and investigations on the mechanisms of chromosomal diversity in Astyanax.
\end{abstract}

Keywords:: Ag-NOR, cytotaxonomy, fish, fluorochromes, South America.

Received: May 3, 2012; Accepted: August 31, 2012.

The Contas River basin in the northeastern Brazilian state of Bahia is characterized by a diverse ichthyofauna that includes several endemic species; this diversity reflects the independent evolutionary history of coastal rivers in eastern South America (Jacobina et al., 2009). However, although a few species from this region have recently been described (Vari et al., 2010), the biota of this basin is still poorly known. This is particularly true for the fish fauna of the headwaters, despite the fact that these habitats represent an excellent model for evolutionary studies because of the occurrence of isolated populations and peculiar ecological niches. Small characids, such as Astyanax Baird and Girard, 1854 species are usually dominant in headwaters and small tributaries throughout South America (Bertaco and Lucena, 2010).

Astyanax (Characidae, Incertae sedis) is one of the most cytogenetically (Kavalco et al., 2011; Mendes et al., 2011) and morphologically diverse fish genera within the Characiformes, with more than 100 Neotropical species (Bertaco and Lucena, 2010). Recent phylogenetic inferences based on molecular data have shown that the family Characidae is a monophyletic group, despite encompassing several polyphyletic species-rich genera such as Astyanax,

Send correspondence to Paulo Roberto Antunes de Mello Affonso. Departamento de Ciências Biológicas, Universidade Estadual do Sudoeste da Bahia, Rua José Moreira Sobrinho s/n, 45206-190 Jequié, BA, Brazil. E-mail: paulomelloaffonso@yahoo.com.br. collectively referred to as Incertae sedis (Oliveira et al., 2011). Because of their controversial taxonomy and extensive chromosomal variation, several species complexes have been proposed in this group, such as Astyanax scabripinnis (Moreira-Filho and Bertollo, 1991), A. hastatus (Kavalco et al., 2009), A. altiparanae - often cited as A. bimaculatus (Kavalco et al., 2011) - and $A$. eigenmanniorum (Mendes et al., 2011). The species in the A. fasciatus complex are characterized by a wide distribution throughout coastal river basins in Brazil and show marked structural and numerical chromosomal variation, including the coexistence of distinct karyomorphs in a single basin (Medrado et al., 2008).

In this report, we describe the karyotypic structure of two sympatric Astyanax species from the Middle Contas River basin in the northeastern Brazilian state of Bahia. The data described here reinforce the peculiar biogeographic history and remarkable endemism of this region.

Eighteen specimens of Astyanax sp. (12 females, four males and two juveniles) and 26 specimens of Astyanax aff. fasciatus (10 females, 14 males and two juveniles) were collected in sympatry and syntopy along the Preto do Crisciúma River (13 $555^{\prime} 38^{\prime \prime}$ S/39 $57^{\prime} 53^{\prime \prime}$ W), a tributary of the Contas River, within the Crisciúma-Guariba microbasin, northeastern Brazil (Figure 1). The specimens of Astyanax sp. were deposited in the Zoology Museum of the Universidade Federal da Bahia, Brazil (UFBA 5528) while 


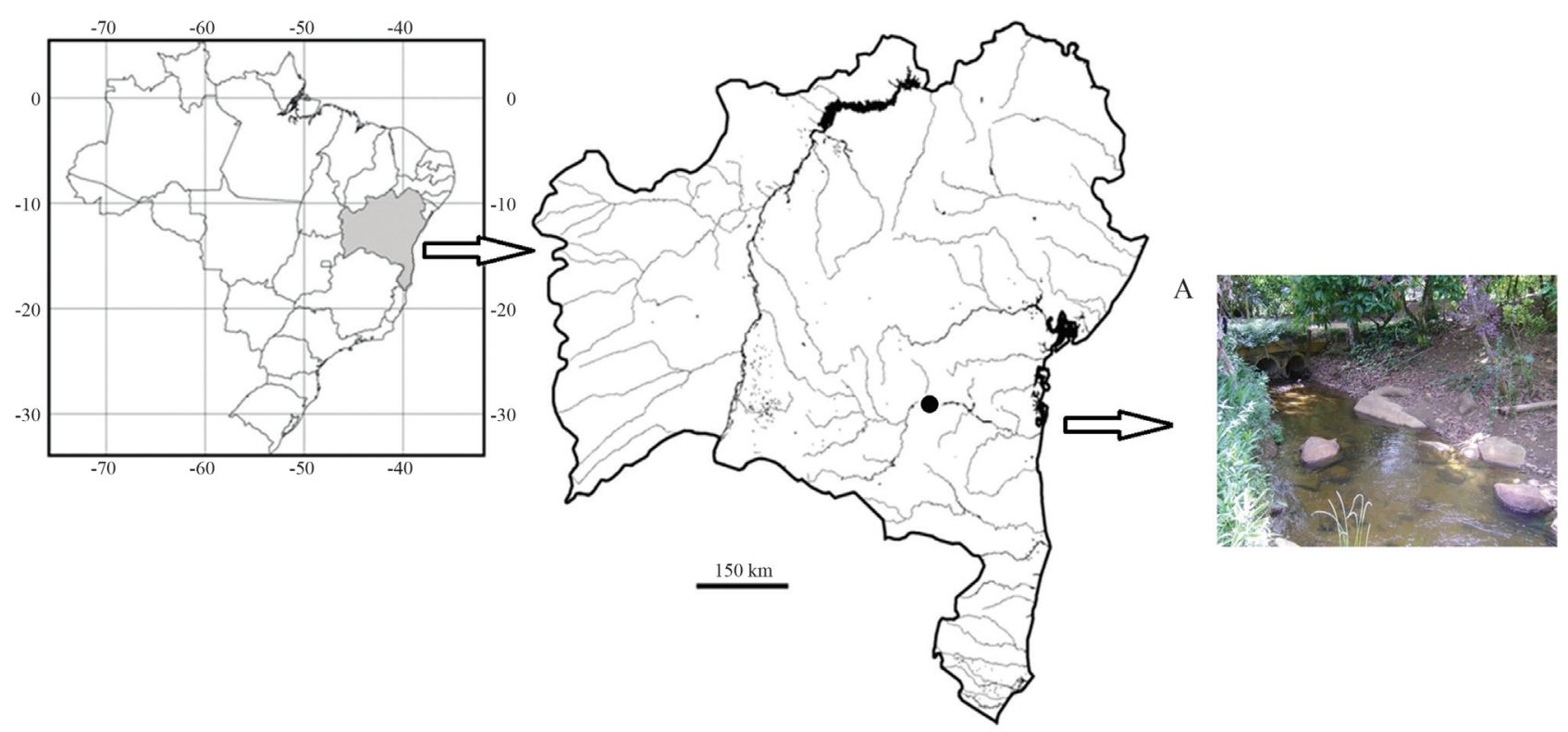

Figure 1 - Map of Bahia state, Brazil, showing Preto do Crisciúma River in the Guariba-Crisciúma microbasin of the Middle Contas River basin, with a view of the collection site (A).

Astyanax aff. fasciatus were identified and deposited in the fish collection of the Universidade Estadual do Sudoeste da Bahia, Brazil (CR 348, 349, 350, 353, 418, 482, 484, 693, 694, 728, 730, 734, 1227, 1228, 1229, 1232, 1233, 1234, 1289, 1290, 1291, 1300, 1301, 1302, 1303).

Chromosomes were obtained from anterior kidney cells after mitotic stimulation (Bertollo et al., 1978). Heterochromatin was visualized by C-banding (Sumner, 1972) and nucleolar organizer regions (NORs) were located by silver nitrate staining (Howell and Black, 1980). Five specimens of each species were used in Ag-NOR studies, with at least 30 metaphase counts per individual. The GC- and AT-rich regions were detected by base-specific fluorochrome staining using chromomycin $\mathrm{A}_{3}\left(\mathrm{CMA}_{3}\right)$ and 4',6-diamidino-2-phenylindole (DAPI), respectively (Schmid, 1980). Chromosomal morphology was established based on the arm ratio and arranged in order of decreasing size (Levan et al., 1964). The fundamental number (FN) was calculated by assuming that metacentric (m), submetacentric (sm) and subtelocentric (st) chromosomes are biarmed while acrocentric chromosomes (a) have a single chromosomal arm.

Astyanax sp. and Astyanax aff. fasciatus had $2 \mathrm{n}=48$, although the species could be differentiated by their chromosomal morphology, i.e., $10 \mathrm{~m}+18 \mathrm{sm}+08 \mathrm{st}+12 \mathrm{a}$ and $\mathrm{FN}=84$ for Astyanax sp. (Figure 2A) and $08 \mathrm{~m}+28 \mathrm{sm}+08 \mathrm{st}+04 \mathrm{a}$ and $\mathrm{FN}=92$ for Astyanax aff. fasciatus (Figure 2B). Furthermore, the first sm and st pairs in individuals of $A$. aff. fasciatus were remarkably larger than the others within their respective morphological classes (Figure 2B). No sex-related differences were observed in the samples analyzed.
Faintly-stained heterochromatin blocks were observed in the pericentromeric regions of all chromosomes in both species (Figure 2A,B). In Astyanax aff. fasciatus, some terminal heterochromatin segments were observed on long arms in one homolog from pairs 23 and 24 (Figure 2B).

Silver nitrate-stained NORs (Ag-NORs) were located in the terminal regions of up to four chromosomes, including the short arms of two st chromosomes and long arms of an st and one a chromosome in Astyanax sp. (Figure 2C) and the short arms of one sm pair and long arms of one st and one a chromosome in Astyanax aff. fasciatus (Figure 2E).

Fluorochrome staining showed differences in the distribution of GC-rich sites between both species. Astyanax sp. presented eight terminal $\mathrm{CMA}_{3}{ }^{+} / \mathrm{DAPI}^{-}$signals on the short arms of two non-homologous $m$ chromosomes and five st chromosomes and on the long arms of one a chromosome (Figure 2C,D). Astyanax aff. fasciatus showed terminal GC-rich signals on the short arms of one large $m$ chromosome and a sm pair plus the long arms of one st pair, comprising five chromosomes (Figure 2E,F).

Numerical and structural karyotypic variation has been reported among or within populations of Astyanax representatives, including the occurrence of $\mathrm{B}$ chromosomes and polymorphism in heterochromatic bands and/or ribosomal sites. In $A$. aff. fasciatus in particular, sympatric karyomorphs with $2 \mathrm{n}=48$ and 50 were observed in the Tibagi River basin, including a putative hybridization event (Artoni et al., 2006). Similarly, karyomorphs with $2 \mathrm{n}=45$, 46, 47 and 48 are found in this species complex from the Mogi-Guaçu River, southeastern Brazil (Pazza et al., 2006). 

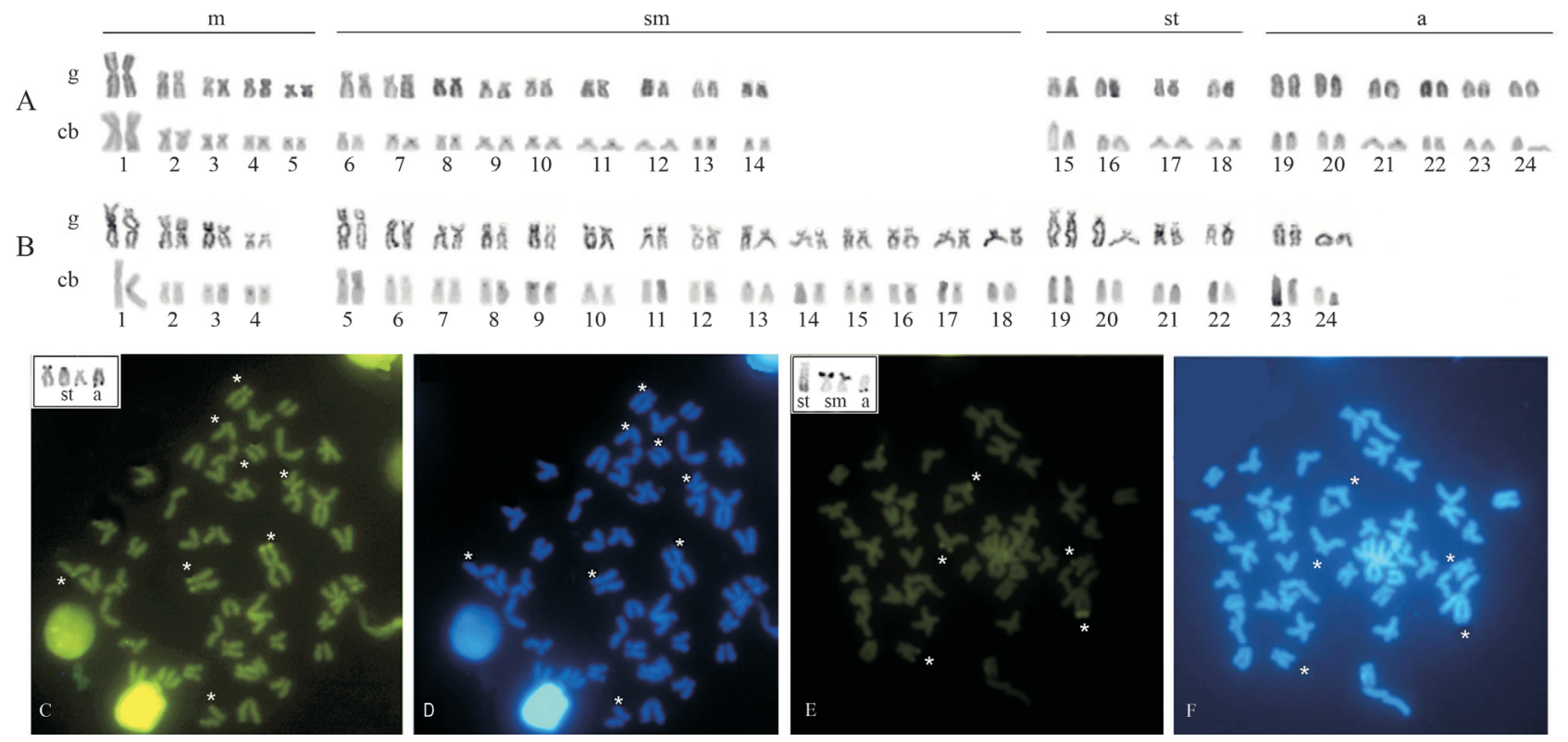

Figure 2 - Karyotypes and metaphases of Astyanax sp. (A,C,D) and A. aff. fasciatus (B,E,F) after Giemsa staining (g), C-banding (cb), CMA staining (C and E) and DAPI staining (D and F). The asterisks indicate the $\mathrm{CMA}_{3}{ }^{+} / \mathrm{DAPI}^{-}$signals. The chromosomes bearing Ag-NORs are shown as insets in boxes $(\mathrm{C}$ and $\mathrm{E})$.

Although phylogenetic analyses have confirmed that Astyanax and other small characins are polyphyletic groups (Oliveira et al., 2011), it has been suggested that $2 \mathrm{n}=50$ would be a plesiomorphic feature for most characids (Pazza and Kavalco, 2007; Kavalco et al., 2011). Consequently, the populations of $A$. aff. fasciatus and Astyanax sp. may represent a derived group in which chromosomal fusions reduced the diploid number from $2 n=50$ to $2 n=48$. Besides sharing the same chromosomal number and ecological traits, both species are also characterized by an asymmetric karyotype. Another cytogenetic similarity in these samples was the presence of an initial large $m$ pair in relation to other chromosomes. In contrast to $2 n=48$, this pattern is frequent in small characins and is considered another symplesiomorphic feature for Astyanax (Kavalco et al., 2011; Mendes et al., 2011).

The karyotype formulae differed between the two species studied and reinforced the role of pericentric inversions in the chromosomal evolution of Astyanax (Medrado et al., 2008). It should also be noted that $A$. aff. fasciatus showed accentuated size differences in the first sm and st pairs in relation to other pairs, in agreement with a trend reported in ' $2 \mathrm{n}=48$ ' karyomorphs of $A$. fasciatus from southeastern Brazil (Pazza et al., 2006). Furthermore, no intermediate or variant karyotypic forms were detected, i.e., there was no evidence of hybridization among specimens bearing polymorphic chromosomes (Pazza et al., 2006; Kavalco et al., 2009).

Apart from macrostructural traits, Ag-NORs were also useful as cytotaxonomic markers. The multiple AgNOR system observed here, which involves the terminal regions of up to four chromosomes, was similar to the pattern observed in other populations of $A$. fasciatus (Medrado et al., 2008) and A. aff. bimaculatus (Pamponet et al., 2008) from the Contas River basin. However, the species we examined could be differentiated by the chromosomal location of the NORs (Figure 2). This location was possibly influenced by the translocation or transposition of rDNA to distinct chromosomes and revealed the dynamic evolution of ribosomal cistrons in this genus (Mantovani et al., 2000).

Despite the importance of C-banding for karyoevolutionary inferences, little is known about the distribution of heterochromatin in Astyanax from coastal basins in northeastern Brazil. As with other Astyanax species, such as $A$. giton and A. intermedius (Kavalco et al., 2007) and $A$. jacuhiensis (Pacheco et al., 2010), the heterochromatin in the specimens studied here was restricted mainly to pericentromeric regions; such a distribution is regarded as a basal C-banding pattern in fish. Some species or populations of Astyanax from coastal basins tend to have a reduced amount of heterochromatin, usually close to centromeres and NORs (Rosa et al., 2009; Kavalco et al., 2011). Our findings corroborated this hypothesis and extended this trend to northeastern coastal rivers in South America.

The fluorochrome staining described here is the first for populations of Astyanax from northeastern Brazilian coastal rivers. In both species studied, the $\mathrm{CMA}_{3}{ }^{+} / \mathrm{DAPI}^{-}$ signals were usually coincident with NORs. Although a correlation between $45 \mathrm{~S}$ rDNA clusters and GC-rich blocks is common in fish (Verma et al., 2011) this technique is more appropriate for characterizing repetitive DNA segments, as proposed for Astyanax scabripinnis (Mantovani et al., 2004). Another peculiar feature observed in both spe- 
cies was the presence of size differences and heterozygous fluorescent signals, which suggested quantitative differences in the GC content between homologs. In addition, the location of GC-rich sites revealed striking species-specific distribution patterns that confirmed their evolutionary isolation.

The high karyotypic diversity of Astyanax species when compared to other Neotropical fish groups is thought to be related to the biological traits of these small characins. Their common geographic isolation in headwaters would favor the fixation of interpopulation differences, resulting in the formation of species complexes (Bertaco and Lucena, 2010). Also, the occurrence of such isolates in small streams could maximize the effects of genetic drift and cause intraspecific polymorphism. The present data for $A$. aff. fasciatus and Astyanax sp. support both inferences since chromosomal differences were observed in each species close to headwaters in a small stream from the Middle Contas River basin.

The origin of these sympatric species remains unclear since they share a similar habitat and most likely have overlapping ecological niches. Pre-zygotic isolation related to species-specific reproductive behavior or ancient geographic barriers followed by headwater capture could account for the speciation and chromosomal differentiation of both forms. This possibility requires further investigation.

In conclusion, the chromosomal analysis described here was effective in detecting single evolutionary units in Astyanax from the Contas River basin, one of several isolated coastal basins in northeastern Brazil for which there is insufficient knowledge and increased habitat degradation. We suggest that cytogenetic analyses, together with traditional taxonomic methods, would provide a low-cost, highly informative approach for characterizing the biodiversity of these tropical fish.

\section{Acknowledgments}

This work was supported by CAPES and FAPESB. The samples were collected with the authorization of the Brazilian environmental agency ICMBio/SISBIO (license number 26752-1).

\section{References}

Artoni RF, Shibatta OA, Gross MC, Schneider CH, Almeida MC, Vicari MR and Bertollo LAC (2006) Astyanax aff. fasciatus Cuvier, 1819 (Teleostei, Characidae): Evidences of a species complex in the upper Rio Tibagi basin (Paraná, Brazil). Neotrop Ichthyol 4:197-202.

Bertaco VA and Lucena CAS (2010) Redescription of Astyanax obscurus (Hensel, 1870) and A. laticeps (Cope, 1894) (Teleostei, Characidae): Two valid freshwater species originally described from rivers of southern Brazil. Neotrop Ichthyol 8:7-20.
Bertollo LAC, Takahashi CS and Moreira-Filho O (1978) Cytotaxonomic considerations on Hoplias lacerdae (Pisces, Erythrinidae). Braz J Genet 1:103-120.

Howell WM and Black DA (1980) Controlled silver staining of nucleolus organizer region with protective colloidal developer: A 1-step method. Experientia 36:1014-1015.

Jacobina U, Affonso PRAM, Carneiro PLS and Dergam JA (2009) Biogeography and comparative cytogenetics between two populations of Hoplias malabaricus (Bloch, 1794) (Ostariophysi, Erythrinidae) from coastal basins in the State of Bahia, Brazil. Neotrop Ichthyol 7:617-622.

Kavalco KF, Pazza R, Bertollo LAC and Moreira-Filho O (2007) Satellite DNA sites of four species of the genus Astyanax (Teleostei, Characiformes). Genet Mol Biol 30:329-335.

Kavalco KF, Brandão KO, Pazza R and Almeida-Toledo LF (2009) Astyanax hastatus Myers, 1928 (Teleostei, Characidae): A new species complex within the genus Astyanax? Genet Mol Biol 32:477-483.

Kavalco KF, Pazza R, Brandão KO, Garcia C and AlmeidaToledo LF (2011) Comparative cytogenetics and molecular phylogeography in the group Astyanax altiparanae Astyanax aff. bimaculatus (Teleostei, Characidae). Cytogenet Genome Res 134:108-119.

Levan A, Fredga K and Sandberg AA (1964) Nomenclature for centromeric position on chromosomes. Hereditas 52:201220.

Mantovani M, Abel LDS, Mestriner CA and Moreira-Filho O (2000) Accentuated polymorphism of heterochromatin and nucleolar organizer regions in Astyanax scabripinnis (Pisces, Characidae): Tools for understanding karyotypic evolution. Genetica 109:161-168.

Mantovani M, Abel LDS, Mestriner CA and Moreira-Filho O (2004) Evidence of the differentiated structural arrangement of constitutive heterochromatin between two populations of Astyanax scabripinnis (Pisces, Characidae). Genet Mol Biol 27:536-542.

Medrado AS, Figueiredo AVA, Waldschmidt AM, Affonso PRAM and Carneiro PLS (2008) Cytogenetic and morphological diversity in populations of Astyanax fasciatus (Teleostei, Characidae) from Brazilian northeastern river basins. Genet Mol Biol 31:208-214.

Mendes MM, Rosa R, Giuliano-Caetano L and Dias AL (2011) Karyotype diversity of four species of the incertae sedis group (Characidae) from different hydrographic basins: Analysis of AgNORs, $\mathrm{CMA}_{3}$ and $18 \mathrm{~S}$ rDNA. Genet Mol Res 10:3596-3608

Moreira-Filho O and Bertollo LAC (1991) Astyanax scabripinnis (Pisces, Characidae): A species complex. Braz J Genet 14:331-357.

Oliveira C, Avelino GS, Abe1 KT, Mariguela TC, Benine RC, Ortí G, Vari RP and Castro RMC (2011) Phylogenetic relationships within the speciose family Characidae (Teleostei, Ostariophysi, Characiformes) based on multilocus analysis and extensive ingroup sampling. BMC Evol Biol 11:275.

Pacheco RB, Giuliano-Caetano L, Horácio Jr FJ and Dias AL (2010) Cytogenetic data on Astyanax jacuhiensis (Characidae) in the Lago Guaíba and tributaries, Brazil. Neotrop Ichthyol 8:667-671.

Pamponet VCC, Carneiro PLS, Affonso PRAM, Miranda VS, Silva Jr JC, Oliveira CG and Gaiotto FA (2008) A multiapproach analysis of the genetic diversity in populations of 
Astyanax aff. bimaculatus Linnaeus, 1758 (Teleostei, Characidae) from northeastern Brazil. Neotrop Ichthyol 6:621-630.

Pazza R and Kavalco KF (2007) Chromosomal evolution in the Neotropical characin Astyanax (Teleostei, Characidae). Nucleus 50:519-543.

Pazza R, Kavalco KF and Bertollo LAC (2006) Chromosomal polymorphism in Astyanax fasciatus (Teleostei, Characidae) I. Karyotype analysis, Ag-NOR and mapping of the $18 \mathrm{~S}$ and $5 \mathrm{~S}$ ribosomal gene in sympatric karyotypes and their possible hybrid forms. Cytogenet Genome Res 112:313-319.

Rosa R, Rubert M, Malabarba LR, Martins-Santos IC and Giuliano-Caetano L (2009) Cytogenetic analysis of Astyanax laticeps (Cope, 1894) (Ostariophysi, Characidae) from the Laguna dos Patos system. Neotrop Ichthyol 7:601-605.
Schmid M (1980) Chromosome banding in Amphibia. IV. Differentiation of GC- and AT-rich chromosome regions in Anura. Chromosoma 77:83-103.

Sumner AT (1972) A simple technique for demonstrating centromeric heterochromatin. Exp Cell Res 75:304-306.

Vari RP, Zanata AM and Camelier P (2010) New species of Cyphocharax (Ostariophysi, Characiformes, Curimatidae) from the Rio de Contas drainage, Bahia, Brazil. Copeia 3:382-387.

Verma J, Lakrai WS, Kushwaha B, Sirajuddin M, Nagpure NS and R Kumar (2011) Characterization of two freshwater silurid catfish using conventional and molecular cytogenetic techniques. J Genet 90:319-322.

Associate Editor: Fausto Foresti

License information: This is an open-access article distributed under the terms of the Creative Commons Attribution License, which permits unrestricted use, distribution, and reproduction in any medium, provided the original work is properly cited. 